\title{
SYRACUSE AS VIETNAM: THE CLASSICAL INTERTEXT OF JOSEPH HELLER'S PICTURE THIS ${ }^{1}$
}

\author{
F Pauw (Stellenbosch University)
}

\section{$1 \quad$ Introduction}

This article explores the classical intertext of Joseph Heller's 1988 novel Picture This and its concern with ancient Greek and modern American wars. First, the challenges which the generic peculiarities of the work pose to its interpretation will be investigated. Next, Heller's postmodernist narrative devices and their effect will be evaluated. Since Picture This deals in large part with classical Athenian history and philosophy, ${ }^{2}$ this article will also examine Heller's use of classical sources, including certain factual and terminological errata. The penultimate section argues that Heller's critical concern with wars and imperialism in classical Athens relates to his perception of the American involvement in the Vietnam War. Finally, I suggest that while Heller's novel can be read as a warning against the corruptive power of politics and war, he remains sceptical of mankind's ability to learn from history.

\section{The author}

American novelist Joseph Heller studied in both New York and Oxford. In 1961, his first and best-known work, Catch-22, was published. This darkly comic novel, based on Heller's experiences as a bombardier in the Mediterranean in World War II (mishalov.com) but also influenced by Homer's Iliad (Reilly \& Heller 1998:508, 518), became a universal metaphor for the insanity of war. It became an American classic. Heller asserted that it was "far more factually descriptive of Vietnam than of World War Two" (Seed 1989:74). His own anti-war sentiments found further expression when he spent the 60's touring college campuses, speaking out against the war in Vietnam. In the next decades he wrote a further six novels, two quasimemoirs, short stories, and a few plays (mishalov.com), while never wavering in his exposure of the hypocrisy and greed of politicians, warmongers and corporate capitalists, as for instance in Good as Gold (1979) (Reilly \& Heller 1998:508; Potts 1982:53). His Weltanschauung is that of "the liberal imagination", to borrow Lionel Trilling's phrase (Stern 1988:34); his rich humour, high satire and relentless experimentation have earned him professorships, ${ }^{3}$ various honours and millions of readers (Reilly \& Heller 1998:507). Joseph Heller died in 1999. The title of Picture This, published in 1988, alludes to the central role played in the novel by a Rembrandt painting.

I wish to thank the anonymous referees for their valuable suggestions and corrections.

Chapters dealing with the other main focus of Heller's novel, seventeenth-century Amsterdam, fall outside the scope of this article.

For instance, at Oxford and Yale. 
Picture This has been classified amongst Heller's novels, and for convenience's sake I adhere to this classification. In actual fact, however, this work is difficult to classify generically, sharing, as it does, characteristics of a novel, historiography, a meditative essay and satire. ${ }^{4}$ A fully-fledged novel it is not, for it lacks plot and character development (although it has a protagonist of sorts in the character Aristotle); its central "message" is far from clear. It could not even be called an historical novel or a documentary novel. As a compromise, it could simply be called "faction", i.e. a conflation of historical facts and fictional elements (Van Heerden 1994:5). ${ }^{5}$ Linda Hutcheon (1988:5) has coined the term "historiographic metafiction" to refer to works that fictionalise actual historical events or figures: "[...] novels which are both intensely self-reflexive and yet paradoxically also lay claim to historical events and personages". 6

As will become apparent, Heller's work of faction is not truly historiographic metafiction, for its fictionality is more limited and its historiographic aspect less integrated into a novelistic form than any of Hutcheon's examples. It is narrated by an omniscient narrator; the narrative voice is regarded by Craig (1997:187) as "impersonal — aside from its telling relationship to the opinions of Joseph Heller. ${ }^{7}$ It resembles the narrating voice of a documentary film." It proceeds by accumulation, "with Heller marshalling detail after detail until the reader is numbed by them" (Craig 1997:186). Heller's narrative strategy is postmodernist in that his novel is a pastiche, or a collage, of seemingly unrelated themes which are narrated, for the most part, in a non-linear and non-diachronic fashion, so that coherence is sacrificed.

Heller's ostensible subject is announced in the first sentence of the novel, where some light is shed on the front cover picture:

Aristotle contemplating the bust of Homer thought often of Socrates while Rembrandt dressed him with paint [...] (p. 13). ${ }^{8}$

$4 \quad$ Regarding the fluidity of genre boundaries in postmodern literature, Hutcheon 1988:9 asks the rhetorical question: "Who can tell anymore what the limits are between the novel and the short story collection (Alice Munro's Lives of Girls and Women), the novel and the long poem (Michael Ondaatje's Coming Through Slaughter), the novel and autobiography (Maxine King's China Men), the novel and history (Salman Rushdie's Shame), the novel and biography (John Banville's Kepler)?"

5 Hutcheon 1988:105 argues that "it is this very separation of the literary and the historical which is now being challenged in postmodern theory [...]"; "It is part of the postmodernist stand to confront the paradoxes of fictive / historical representation, the particular / the general, and the present / the past" (106). As an example, she refers to Norman Mailer's The Armies of the Night, which is subtitled History as a Novel, the Novel as History (117).

$6 \quad$ Hutcheon's examples include The French Lieutenant's Woman, Midnight's Children, Flaubert's Parrot, The Name of the Rose, One Hundred Years of Solitude and The Tin Drum.

7 In this article, the opinions of the narrator, or the authorial persona, are ascribed to Joseph Heller.

8 Page and chapter numbers of, as well as quotations from, Picture This are based on the Picador / Pan edition of 1988 . 
It later ${ }^{9}$ transpires that the painting called Aristotle contemplating the Bust of Homer was commissioned in 1652 and finished by Rembrandt van Rijn in 1653. The novel therefore meanders, and frequently jumps to and fro, between the fifth-century BC Athens of Socrates, the fourth-century Athens of (Plato and) Aristotle, the seventeenth-century Amsterdam of Rembrandt and, occasionally, even the twentiethcentury USA and its foreign policy. Rembrandt's painting of Aristotle thus functions, as David Seed (1989:206) puts it, as "an ingeniously versatile object linking the fifth century BC with the seventeenth and twentieth centuries". In Heller's description of fifth-century Athens, much emphasis is placed on the consequences of the imperialism of Pericles and Alcibiades (i.e. the defeat of Athens by Sparta in the Peloponnesian War in 404 BC), and on the philosophy of Socrates and his trial and death in 399; in fact, these parts of the novel ${ }^{10}$ differ from the rest in that they are narrated in a more straightforwardly linear and diachronic manner. The fourthcentury Athenians Plato (as the intellectual heir of Socrates) and Aristotle (as the subject of the painting and a counterweight to Plato's philosophical idealism) receive abundant attention. In view of Aristotle's foregrounding in the painting, of his being imbued with cognition and a voice, and thus of his role as mediator between Athens and Amsterdam, ${ }^{11}$ a surprising degree of prominence is given to Socrates and Plato. ${ }^{12}$ Rembrandt's Amsterdam is described not only as a flourishing centre of commerce, the arts and philosophy, but also as a launching pad for mercantilist and colonialist enterprises between 1584 and 1652. Of Homer, little is said. ${ }^{13}$ On at least three occasions, ${ }^{14}$ Heller ventures into the more recent past when the peregrinations of the painting between $1653^{15}$ and $1961^{16}$ are described. In the yet more recent past, twentieth-century wars and imperialism are criticised when US policy in Vietnam, as a parallel to that of fifth-century Athens, comes under attack. ${ }^{17}$

\section{$4 \quad$ Narrative devices}

Joseph Heller is an ingenious author who thrives on experimentation. In Section 3, some of Heller's narrative devices were discussed in advance because they have a bearing on the genre of the novel. In this section, I examine certain narrative devices which frame his treatment of classical material: first, his use of the absurd and irony;

9 Pages 16, 243 et al.

10 Chapters 15-20, 22-25 and 33-36.

11 See Section 4.2.

12 Heller clearly has a more than passing interest in Socratic irony and the Socratic method. A review of his novel Closing Time by Pieter Steinz 1994:4 is titled "Socrates in New York"; for a study of the function of the elenchus in his novel Something Happened, see Furlani 1995:252-270.

See pp. 14-15, 186-187 and 273.

Chapters 2, 14 and 32.

When the Sicilian nobleman Don Antonio Ruffo paid 500 guilders for it.

When it came to rest in the Metropolitan Museum of Art in New York.

My focus is on Heller's depiction of wars and power struggles in classical Athens and on mankind's proclivity for repeating her errors; other matters of interest to Heller, such as seventeenth-century Holland and the role of money, whether in Aristotle's philosophy or in Rembrandt's household, fall outside the scope of this article. 
next, his creation of Aristotle as a magical-realist character who, although he is the subject of a painting, is imbued with cognition; and finally, his use of historiographic metafiction to create fabrications. All of these techniques can be associated with postmodernism. This section should not be viewed as an isolated excursus on aesthetics, but as a logical prelude to Heller's treatment of classical sources (Section 5) and his views on imperialism (Section 7). Indeed, the examples provided in this section not only illustrate Heller's narrative idiosyncrasies but also happen to involve either classical personages and themes, or imperialism.

\subsection{Para prosdoketon wit}

Joseph Heller's fame rests in part on the brand of absurd humour which was instrumental in creating the title of Catch $-22^{18}$ and which has been a trademark of his novels since then. In this section, I briefly examine the function of one specific type of humour: Heller's juxtaposition of the unexpected, what the ancient Greeks would call para prosdoketon or aprosdoketon. With reference to Heller, Seed (1989:195) remarks that "[t]he oxymoron stands as a pattern behind these statements which often bizarrely unite opposites [...]". Such utterances frequently have the characteristics of brief aphorisms or epigrams.

The following examples of absurd humour are concerned with politics, with the rationalisations for external and civil war, and with an unusual perspective on peace.

Juxtaposing the Cold War antagonisms between Athens and Sparta, the Netherlands and Spain, and especially the United States and Russia, Heller ironically argues that

The government of each was helpless without the threat from the other. [...]

It is easy [...] to picture the chaos that would result in both from a sudden outbreak of peace.

Peace on earth would mean the end of civilization as we know it (p. 100).

In a later passage, peace seems to play a similarly sinister role:

"We make war that we may live in peace", said Lyndon Johnson, quoting Aristotle, who was embarrassed, and paraphrasing Adolf Hitler.

The desire of some men for peace is a frequent cause of war (p. 132).

18 The following explanation of the "logic" behind the term Catch-22 is given by mishalov.com: "[Bombardier John] Yossarian concocts a mysterious liver ailment, sabotages his plane and tries to get himself declared insane. Yossarian discovers that, in the military rule book, anyone who is declared insane must be excused from flying death-defying missions. The catch is that one must ask to be excused. But anyone who is smart enough to show 'rational fear in the face of clear and present danger' obviously is sane and must continue to fly". The source fails to mention that the number 22 in the title does not appear to have any significance. 
Heller shows a special interest in the civil war on Corcyra, ${ }^{19}$ and summarises the ideological stances of the respective parties as follows:

Each side claimed its rebel factions were fighting for freedom.

Both sides were right.

The democrats were fighting against a tyranny of a minority.

The oligarchs were fighting against a tyranny of the majority (p. 174).

Heller's laconic comment hits the mark, and could be applied to comparable situations today and for as long as a deadlock exists in which democrats and oligarchs threaten each other.

With reference to the death in battle of the Athenian general Cleon and his Spartan counterpart Brasidas at Amphipolis in 422 BC, Heller remarks:

An endearing feature of Greek wars then was that people advocating them often died in them (p. 201).

Both Brasidas and Cleon embraced war: the former because it would enhance his reputation; the latter because it would cover his defects. As far-fetched as Heller's remark may sound today, it was literally true in an age when generals still had to lead their troops in battle. Together with ostracism, it provided a continuous - and sometimes, one could add, serendipitous — turnover of would-be stratégoi.

In a chapter ostensibly on Plato, Heller has the following cynical comment to make on what is clearly a pet hate of his:

[...] In 1947, the U.S. Department of War [...] was [...] reconstituted as the Department of Defense [...].

And from that day to the present, the United States of America was never again in danger of war.

It was in danger of defense (p. 272).

A feature of Heller's barbed wit is that it is frequently directed at warmongers, thus underscoring what is probably the main serious "message" of Picture This, i.e. a warning against imperialist wars. ${ }^{20}$ Linda Hutcheon (1988:39) reminds us that, as Umberto Eco has said about both his own historiographic metafiction and his semiotic theorising, the "game of irony" is intricately involved in seriousness of purpose and theme. Heller might be temperamentally incapable of not being funny, but he is no mere buffoon.

\subsection{Aristotle looking into Rembrandt's world}

When Heller depicts historical characters from Graeco-Roman antiquity or seventeenth-century Holland, they are treated "objectively" in the sense that the

See n. 51 .

See Section 7. 
distance between Heller in 1988 and Pericles in 440 BC, or Alcibiades in 414 BC, or Rembrandt in 1652, remains constant and the characters lack the omniscience of the author. Pericles cannot escape to the twentieth century; Rembrandt is forever fossilised in the seventeenth. There is, however, one exception to this pattern: Aristotle. Since Heller's Aristotle is not only a fourth-century philosopher but also the subject of a seventeenth-century painting, the author has imbued the subject of the painting with cognition and sensory perception, making him a magical-realist figure and the only possible protagonist of Picture This. But while seeing, hearing and smelling people and objects in Rembrandt's atelier, Aristotle still remains a fourthcentury philosopher with a clear memory of the events of two millennia before. ${ }^{21}$ Thus, he becomes what Seed (1989:204) calls "a major point-of-view character and also a vocal presence". His consciousness is extended beyond its biographical limits (Seed 1989:204), and thus he can comment with equal facility and authority on the events of classical Athens, the Golden Age of Holland, and American imperialism in the twentieth century. ${ }^{22}$ Although Craig (1997:203) correctly regards Aristotle as "the most human of the novel's characters", he adds the proviso that "[e]ven when Heller makes Aristotle's consciousness the narrative voice, he presents it as disembodied [...]" (1997:187).

There are so many instances of Aristotle looking into and tacitly commenting on the worlds of Rembrandt and Socrates that I restrict myself to some of the more noteworthy. ${ }^{23}$ The first example is provided by the very first sentence of the novel, where Heller wastes no time in introducing what appears, at first glance, to be his central subject matter:

Aristotle contemplating the bust of Homer thought often of Socrates while Rembrandt dressed him with paint ... (p. 13).

Thus, the reader is immediately, and disconcertingly, confronted not only with a hotch-potch of characters from seventeenth-century Holland as well as from eightcentury, fifth-century and fourth-century Greece, but also with the unlikely datum that the last character, as the subject of a painting, has powers of cognition.

21 Can the fictional Aristotle be equated with the historical? Applying Eco's term "transworld identity", McHale 1987:35 argues that "[i]f an entity in one world differs from its 'prototype' in another world only in accidental properties, not in essentials, and if there is a one-to-one correspondence between the prototype and its other-world variant, then the two entities can be considered identical even though they exist in different worlds". The reader then intuits that "[...] a historical personage is in some sense the 'same' as his fictional representation in an historical novel". However, in the following discussion a distinction is made between "Aristotle-as-subjectof-the-painting" and "the historical Aristotle".

22 McHale 1987:94 argues that in postmodernist fiction, characters are allowed "to share some of the benefits of their author's hindsight. [...] [John] Barth [in LETTERS and in Flight to Canada] [...] allows his own temporal perspectives to penetrate his fictional world, making his characters into pseudo-prophets, investing them with anachronistic knowledge of their future [...]". Other examples given by McHale of characters demonstrating anachronistic foresight include Carlos Fuentes' Valerio Camillo in Terra Nostra and a number of Ishmael Reed's characters in Mumbo Jumbo. 
A second example of a cognisant Aristotle is provided by a passage in which Rembrandt's perpetually disastrous financial affairs are described, where Heller comments that

Aristotle, in whom the propensity for observing, classifying, correlating, and inferring had remained immutable, could spy the parallel in Socrates approaching his execution and Rembrandt approaching bankruptcy (p. 42).

Aristotle is thus depicted as not only remembering the facts of Socrates' trial and execution that he read or learnt from his mentor, Plato, but also, as subject of Rembrandt's painting, clairvoyantly conversant with the latter's finances.

In a later passage (p. 70), the focus is again on money:

To Aristotle contemplating the bust of Homer, the continuing preoccupation of the world with making money remained an enigma he was not even aware he was unable to decipher. [...]

"A man cannot expect to make money out of the community and to receive honor as well", he had written in Athens in his Nicomachean Ethics.

In Sicily he was no longer positive.

In London and Paris he began to have doubts.

In New York he knew he was wrong [...].

The references to Sicily, London, Paris and New York pertain to the movements and ownership of the painting after completion (pp. 297-317), again imbuing Aristotle-assubject-of-the-painting with a life of his own. In a further twist, Heller's own cynicism regarding the corporate obsession with money (Reilly \& Heller 1998:508) is mirrored by the historical Aristotle's aloof attitude towards money, to which reference is made elsewhere in Picture This. ${ }^{24}$ Aristotle's emotional response on completion of the painting is worth quoting in full:

"I am finished with him [i.e. Aristotle]", said Rembrandt. "I'm waiting for it [i.e. the painting] to dry."

Aristotle felt chilly and wet. Cooped up all day in a studio in a country whose cloudy, damp climate he detested, he could not wait for the war ${ }^{25}$ to end. His eyes were rheumy. His look was dejected, his complexion jaundiced. The smell of the paint was making him sick. He had nothing to do.

"It would be a tragedy", said Rembrandt almost casually, "if I stopped [...] now when I am working so well. [...]"

Tragedy? Aristotle almost sneered. This wasn't tragedy. Didn't they know that tragedy was an imitation of an action that was serious, complete, and of a proper magnitude, in language that was poetically embellished, that was

\footnotetext{
$24 \quad$ E.g. on pp. 55, 63, 186 and 292.

25 The Anglo-Dutch War, 1653.
} 
dramatic rather than narrative in form, and that, by evoking pity and fear, brought about a purging of those emotions? This was pathos, nothing more than one of the ordinary miseries of life, without the salutary compensations of catharsis that tragedy was said by him to confer" (p. 133). ${ }^{26}$

This passage is striking for three reasons. In the first place, Aristotle, as the subject of the painting, shows a sensory reaction to his surroundings: he dislikes the climate of Holland and shows an olfactory allergy to Rembrandt's paint. Secondly, the use of the word "tragedy" gives Heller occasion to allude to Aristotle's famous definition of tragedy in the Poetics Chapter $6 .{ }^{27}$ In the course of a serious discussion of dramatic poetry this allusion would have been normal; here, however, it is unexpected and humorous. And thirdly, it once again depicts Aristotle as a tetchy know-all who cannot help correcting the perceived mistakes of lesser mortals.

In two further passages Aristotle-as-subject-of-the-painting refers to the Poetics. The first reference has a bearing on the bust of Homer being painted by Rembrandt, and thus, implicitly, on the status of Homer's epic poetry:

Aristotle contemplating Rembrandt painting Aristotle Contemplating the Bust of Homer had to wonder [...] why Rembrandt [...] was [...] painting him contemplating a bust of Homer, of whose works he had grown weary by the time he completed his edition of the Iliad for Alexander [...]

Furthermore, in his Poetics he had downgraded Homer inferentially by rating epics below tragedy $[\ldots]$

His Poetics embarrassed him now, and not just because he had failed to complete it. Why in heaven's name was he perambulating about his Lyceum lecturing on Aeschylus, Sophocles, and Euripides when Aeschylus had been dead a hundred twenty-five years and Sophocles and Euripides about seventy-five? (pp. 186-187).

The historical Aristotle does rate epic below tragedy. In Poetics Chapter $26,{ }^{28}$ he argues that tragedy is superior to epic for four reasons:

(i) tragedy contains all the parts of epic plus two more, spectacle and song (1462a14-17);

(ii) tragedy achieves its function in a shorter length of time than epic (1462a18-19);

(iii) tragedy is more unified than epic (1462b3-4);

(iv) tragedy produces its end, i.e. catharsis, more efficiently than epic $(1462 \mathrm{~b} 12-15) .^{29}$

\footnotetext{
26 Elsewhere (p. 194), Jan Six quotes Aristotle as saying that "all great tragedies are imitations of an action".

Arist. Poet. 1449b24-28.

Arist. Poet. $1462 \mathrm{a}-\mathrm{b}$.

For a summary of the four arguments, see Golden \& Hardison 1968:280-281.
} 
It can be debated whether Aristotle actually "failed to complete" the Poetics. The sections on tragedy and epic are complete, even if they are probably lecture notes, and if the promised work on comedy is to be envisaged as separate, then the Poetics is indeed complete; if not, the claim of Aristotle-as-subject-of-the-painting is justified.

The rhetorical question with which the quotation concludes ("Why in heaven's name was he perambulating ...?") reflects Aristotle's style of lecturing, after which his followers (the Peripatetics) ${ }^{30}$ were named. The answer to this question is surely that no fourth-century tragedian could match the fifth-century masters; therefore, the canonised triad of Aeschylus, Sophocles and Euripides, as well as Agathon, even if antiquated in Aristotle's day, simply provided the best exempla to Aristotle.

In one last passage reference to the Poetics is made by the playwright (p. 64) Jan Six, a patron of Rembrandt:

In his Poetics, you know, Aristotle praises you for this portrait of me, commented Jan Six, and Aristotle pricked up his ear. Not by name, of course. He talks of painters. [...] Aristotle instructs dramatists to follow the example of good portrait painters. He says of the good portrait painters that they, while reproducing the distinctive form of the original, make a likeness which is true to life, and yet more beautiful (p. 197).

Here, Aristotle-as-subject-of-the-painting is explicitly imbued with auditory powers, even pricking up his ear. The Aristotelian hypotext for this passage is to be found in the Poetics Chapter $15,{ }^{31}$ where characterisation in drama is discussed. ${ }^{32}$ Seed (1989:197) argues that the function of Jan Six's quotation from Aristotle is to validate the painter's claim of artistic licence, and provides the interesting detail that the working title of Heller's novel was Poetics. ${ }^{33}$

Heller's ingenious creation of Aristotle as an animated character has thus proved to be a highly effective literary device. This has not only given Heller the opportunity to muse on Aristotelian aesthetics, but also to use Aristotle as an omniscient commentator who, alone, can comment retrospectively and prospectively on historical events. Heller's Aristotle-as-subject-of the-painting surely has to be one of the most unusual characters in western literature.

30 The Greek verb $\pi \varepsilon \rho 1 \pi \alpha \tau \varepsilon \hat{\imath} v$ means "to walk about". For speculations about the origin of the term "peripatetic", see Diog. Laert. 5.2.

31 Arist. Poet. 1454b8-11.

32 Hardison's commentary on the Poetics passage reads as follows: "[T]he general rule for tragedy is that agents should be 'good' or, if possible, 'better' than good. The painter draws his portrait so that the quality of 'goodness' shines out more clearly than in life. The poet does likewise. This process may be called 'universalizing' a character. It should not be interpreted to mean 'idealizing"' (Golden \& Hardison 1968:210).

33 Seed 1989:197 provides the following biographical background: "Heller has been familiar with the Poetics possibly since he took his degree at Columbia (where his studies included a course on classical influences on modern literature) and certainly since his spell in the Yale Drama School, where he gave classes on this text". 


\subsection{Fabrications}

It will be demonstrated that Heller is not always in command of his historical facts. ${ }^{34}$ In other cases, he deviates from known history not through sloppiness, but with a conscious agenda. In discussing "historiographic metafiction", and with specific reference to Doctorow's novel Ragtime, Hutcheon (1988:89) speaks of "this mixing of the historical and the fictive and the tampering with the 'facts' of received history". Heller has a similar proclivity for "tampering" with history. Heller afficionados might expect that such pseudo-historical glosses will reflect his trademark brand of wry humour. Let us have a look at some examples of the type of fabrications ${ }^{35}$ which he inserts, unexpectedly, between genuine historical sections, and their function.

The first passage, I quote at some length to give an indication of how Heller's curt, reportorial style gives vent to his type of sardonic wit. In describing Alexander's territorial conquests, Heller adds the following information (pp. 286-287) that will, of course, not be found in Curtius Rufus or Arrian:

In 332 BC Alexander moved down from Babylon and Syria through Palestine into Egypt to make himself Pharaoh there, and word trickled back to Athens of a Hebrew Bible encountered along the way that contained in its first paragraphs a theory of the creation of the universe. Aristotle heard the details and knew it would have to be suppressed.

The account was so simple he was furious he had not thought of it first. Let there be light, and there was light. What could be easier?

There it all was, in a handful of paragraphs.

In the beginning God created the heaven and the earth.

Why hadn't he said that? So much clearer than the Unmoved Mover or Unthinking Thinker or the Prime Unmoved Mover $^{36}$ of his own intricate cosmology. And so much shorter. [...]

Against this Jewish Bible, he did not think his Metaphysics would have a chance.

This clever spoof has two hypotexts: the Old Testament book of Genesis ${ }^{37}$ and Aristotle's Metaphysics. ${ }^{38}$ According to Aristotle's teleological system, all causes can

\section{$34 \quad$ See Section 6.}

35 Hutcheon 1988:153 argues that "[r] eferents can be fictive either because they are imaginary or because they are falsehoods. It is not accidental that one of the constant themes of historiographic fiction is that of lying [...]".

36 Reference to Aristotle's "prime mover" also occurs earlier in the novel: "[...] Aristotle, whose theory of creation in the Metaphysics rests on a prime mover setting the universe rolling and never looking our way again [...]" (p. 58). Elsewhere (p. 189), the first sentence of the Metaphysics is quoted: "All men [...] desire by nature to know".

37 Gen. 1:1: "In the beginning God created the heaven and the earth"; and Gen. 1:3: "And God said: 'Let there be light!' And there was light".

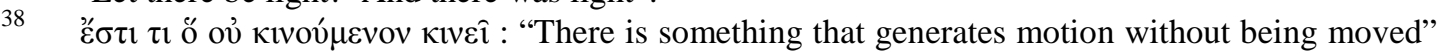
(Arist. Metaph. 1072a25). 
be traced back to an ultimate cause that was not caused by anything preceding it; all movement is caused by what the Scholastic philosophers would call the primum movens, an unmoved and unmovable entity. In Aristotle's vocabulary, this Ultimate Cause, this Unmoved Mover, has the highest ontological status of all beings: it is a philosophical god. Heller's fictional Aristotle is therefore justified in becoming jealous of the monotheistic Hebrew God's relative simplicity, and the simple causality involved in his creation process. The function of this passage, one may deduce, is to satirise not only Aristotle's system of logical deduction and its implications for his teleology and theology, but also his perceived pride and tetchiness.

In another deviation from the accepted facts, Heller mischievously interprets the ending of the Phaedo in such a way that Socrates' last words ("Crito, I owe a cock to Asclepius") are applied not to Asclepius, the god of medicine, but to a member of the jury at Socrates' trial, the tanner Asclepius. This fictional character crops up on the very first page (p. 13), and again intermittently in the course of the novel. ${ }^{39}$ Because he voted for Socrates' acquittal, he was brought to trial a month after the death of Socrates in what Seed (1989:212) calls "a bleakly comic sub-plot". In this trial he admitted under oath "that he had never lent a cock or any other fowl to Socrates or provided him with any goods or services of equivalent value" (p. 267), but in spite of his denial, he was sentenced to death and executed by hemlock the next day (p. 332). When describing the actual death of Socrates at the end of the novel (p. 349), however, Heller refrains from modifying the conventional interpretation. But there is still a surprise in store, for in the penultimate paragraph of the novel the Platonic idealisation of Socrates' death is deconstructed:

Death by hemlock is not as peaceful and painless as he portrays: there is retching, slurring of speech, convulsions, and uncontrollable vomiting (p. 350). ${ }^{40}$

By this qualification, and by the Asclepius subplot, Heller postmodernistically undermines the master narrative of the established Platonic canon.

On two occasions, Heller inserts a fictional dialogue between Plato and Aristotle. The first of these dialogues (pp. 31-32) reads as follows:

"I have this beetle here in one hand", he [Aristotle] proclaimed one day, "with a single oval shell and eight jointed legs, and I have here in my other hand this second beetle of lighter hue which has twelve legs and a shell that is longer and segmented. Can you explain the differences?"

"Yes", said Plato. "There is no such thing as a beetle, in either of your hands. There is no such thing as your hand. What you think of as a beetle and a hand are merely reflections of your recognition of the idea of a beetle and a hand.

See pp. 37-38, 48, 131, 267 and 330-333.

For a fuller discussion, see Gill 1973:25-28. 
[...] What you are holding in what you think are your hands are shadows of that idea. Have you forgotten my illustration of the cave in my Republic?" 41

In a second fictional dialogue (pp. 290-1), Aristotle keeps on questioning Plato about the latter's philosopher-king until Plato, vexed by Aristotle's insistence, answers:

"What difference does it make? What people do in this world is of no consequence". Aristotle, predictably, walks away to count the legs on a beetle (p. 291).

The function of these two dialogues is clearly to highlight the difference in approach of the two great fourth-century philosophers: Plato, head-in-the-clouds, was more interested in the ideal and the cognitive than in the mundane and the concrete, as is borne out by his rejection of sense perception and his espousal of a "realm of Ideas"; ${ }^{42}$ Aristotle, on the other hand, feet-on-the-ground, was more interested in the empirical and the measurable, as witness his research in the natural sciences. This contrast has been well known from antiquity, but Heller gives it extra point by situating it in the sphere of the ludicrous.

Craig (1997:195) claims that "Plato's and Aristotle's voices enact a novellong textual dialogue, without Heller prioritizing, mediating, or resolving their competing claims". One could argue, however, that Plato is at a disadvantage vis-àvis Aristotle, because, as a character, he is denied the consciousness which Aristotle is granted.

Two other fabrications by Heller should be noted. The first, inserted to support the argument that Aristotle's views were unfashionable because he "was unblessed in timing, born too late or too soon" (p. 292), reads as follows:

"It was just my luck", he [Aristotle] wrote in the mammoth autobiography he did not live long enough to complete, of which just that opening fragment of the first sentence survives (p. 293).

The tone of this passage is again determined by the now customary irony of Heller: there is no evidence for an Aristotelian autobiography, mammoth or otherwise.

My last example concerns Alcibiades being credited with the political theory of the domino effect: when state A falls, state B will follow suit. Alcibiades, while still on the side of Athens, applies this to Syracuse:

When Syracuse fell, the cities nearest Syracuse would fall, like dominoes, in sequence, then all of Sicily, then Italy, then Carthage, and then [...] Sparta too would fall (p. 217; cf. p. 224).

As it happens, such an expectation would have been in accord with the expansionist policies of the historical Alcibiades. ${ }^{43} \mathrm{He}$, however, could not have used the anachronistic metaphor of dominoes. It needed the resourcefulness of Heller to latch

\footnotetext{
41 The metaphor of the cave is described in Plato Resp. 514a-518b.

42 For Platonic idealism, see also pp. 259-260.

43 Thuc. 6.15; Plut. Alc. 17.
} 
onto a twentieth-century concept and, with postmodernist irony, ascribe it to antiquity.

\section{$5 \quad$ Classical passages and references}

Picture This is no academic treatise; it is a novel. Accurate source acknowledgement, it could be argued, can therefore be dispensed with. But we have seen that due to the generic peculiarities of Heller's novel, it shares certain characteristics with historiography. In view of Heller's dependence on classical sources, he treats source acknowledgement in a supremely cavalier way. On numerous occasions, he borrows whole passages, sometimes lengthy ones, almost verbatim from recognisable Penguin translations of well-known classical authors; frequently, he paraphrases them. Too often, there is no attempt at source acknowledgement; especially Thucydides has fallen prey to this neglect. ${ }^{44}$

Gérard Genette (1982:11-14, 355-357) makes a distinction between a hypotext (e.g., Homer's Odyssey) and its hypertextual adaptation (e.g., Vergil's Aeneid). This terminology can also be loosely applied to Heller's reworking of his classical source material. His hypertextual adaptation (say, a paraphrase of Thucydides 2.42) becomes a palimpsest through which the original hypotext (Thucydides 2.42), albeit in translation, can all too easily be read. In such cases, source acknowledgement is warranted. As it happens, the use of footnotes with chapter and paragraph numbers in a novel would have been a valid postmodernist ploy (McHale 1987:191; Hutcheon 1989:84).

Heller's most important classical or post-classical sources are Plato and the historiographers Thucydides, Xenophon and Plutarch.

\subsection{Plato's Socrates}

Let us first examine references to Socrates in Heller's novel. David Seed (1989:199) finds that Heller "repeatedly points out disparities and divergences between accounts of Socrates' life". This is rather overstating the case. Although there are a couple of exceptions that support Seed's argument, ${ }^{45}$ Heller's hypotext is usually either an unmodified Socratic dialogue by Plato, or Plato's version of Socrates' defence speech at his trial (the Apologia), or the Laws.

The following themes from the Apologia are mentioned, in paraphrased or quoted form but in no fixed order, in the course of Picture This: Socrates' denial of his imputed oratorical skill (Ap. 17a-b, p. 322) in the opening paragraphs of the Apologia; his examination of the oracle's puzzling answer that he is the wisest man alive (21b-23a, pp. 263-265); his view of himself as "a sort of gadfly attached to the state" (30e, p. 61); his limited public involvement (32a-d, pp. 92-93); a summary of his "teaching" methods (33a-b, pp. 80-82); his rhetorical invitation to young men who have been "corrupted" by him to come forward (33d-34b, pp. 324-325); his

\footnotetext{
44 Thucydides and his translator(s) should in some way have been acknowledged as source for almost the whole of chapters 18-20 and 22-25.

45 See n. 46 and Section 4.3.
} 
refusal to elicit sympathy via his children (34c-35d, p. 326); his proposal of maintenance by the state as a "punishment" (36c-37a, p. 265); his rejection of imprisonment, a fine, or exile as punishment (37b-e, pp. 262-263); his compromise suggestion of a fine of one mina or thirty minae (38b, p. 47); and his advice to his accusers and his acquitters, as well as his views on death (39b-42a, pp. 327-329).

These references are interrupted by excursuses on, for instance, Pericles, Alcibiades, Rembrandt or Aristotle. Only near the end of Picture This, as a prelude to the death of Socrates, is a continuous passage (pp. 322-329) devoted to the Apologia, but even then the sequence of the original is not retained. Yet, surprisingly, Crito follows Apologia chronologically in Picture This. Part of Socrates' argument in Crito (43a-54e ) about obedience to the laws of Athens is summarised when Heller describes Crito's visit to and conversation with Socrates in jail (pp. 334-341). ${ }^{46}$

Quotations from, or implicit allusions to, the hypotext of the Phaedo occur on at least three occasions. The opening lines of Phaedo (61b-e), where Phaedo inquires after the circumstances of Socrates' death, are paraphrased on p. 342. No reference whatsoever is made to the long central argument of the Phaedo, the discussion between Socrates and Simmias about the immortality of the soul; however, Socrates' view of (his own) bodily death is highlighted in the concluding narrative section:

"But how shall we bury you?", his friend Crito asked at the end.

"Any way that you like", answered Socrates. "If you can catch me and I don't slip through your fingers" (115c, pp. 93-94).

And finally, a long passage is devoted to a description of Socrates preparing for and drinking the hemlock (115b-118a, pp. 342-349). ${ }^{47}$ Thus, the Platonic version of the actual sequence of Socrates' last days (Apologia-Crito-Phaedo) is more or less recreated by Heller. ${ }^{48}$

In two other Platonic dialogues referred to by Heller, the emphasis is on the frustration of the interlocutor by Socrates' domination of the discussion. In the first book of the Republic, for instance, Thrasymachus' loses his temper in response to Socrates' evasive and agnostic elenchos (Resp. 336b-c, p. 83); in the Meno, Socrates is compared to a torpedo-fish which paralyses its victim (Meno 79e-80b, p. 84).

On another occasion, Alcibiades' inebriated accolade to Socrates in the Symposium is paraphrased, interspersed with snippets of relevant historical detail (Symp. 212c-222c, pp. 85-91). Alcibiades' physical beauty, social popularity and sexual promiscuity are emphasised as a prelude and a foil to Socrates' extreme selfcontrol (Seed 1989:208). The contrast between the morality of Socrates and Alcibiades highlights the moral dilemma of an imperialist city which had to recall an amoral leader in a last-ditch effort to win a war that was the result of its own hubris, while executing a moral citizen who could have escaped had he not had integrity. ${ }^{49}$

\footnotetext{
46 For the way in which Heller has modified his Platonic hypotext, see Seed 1989:210.

See Section 4.3 for Heller's modification of the hemlock episode.

However, no allusion is made to the Euthyphron.

Other Platonic dialogues which are mentioned or paraphrased include Critias (pp. 75-78), Protagoras (pp. 83, 94), Gorgias (p. 93), Phaedrus (p. 94) and the Laws (pp. 271, 273-277).
} 


\subsection{Historiography}

From the above we see that Heller's depiction of events in classical Athens, and thus, implicitly, his use of the supporting classical sources, normally proceeds in a haphazard, non-linear way. His use of Thucydides as a source for late fifth-century history, however, is exceptional in that Thucydides' History of the Peloponnesian War, occasionally corroborated or complemented by Plutarch, is used as hypotext for a solid narration that occurs in a linear and diachronic fashion and with only one interruption. ${ }^{50}$ This is also, unfortunately, the single hypotext in Picture This that is acknowledged least frequently.

Heller commences his narration of classical Athenian history with a heading titled The Age of Pericles, and in the first chapter the following events preceding the Peloponnesian War are described: Pericles' first post as general and the high Athenian fatalities during the Egyptian expedition of 459-454 (Thuc. 1.104, 109110; pp. 143-144); the Citizenship Act of 451 (Plut. Vit. Per. 37, p. 145); the ThirtyYears Peace with Sparta in 446 (Thuc. 1.115, p. 145); the war against Samos in 440 and Pericles' subsequent funeral speech (Thuc. 1.115-117; Plut. Vit. Per. 28; pp. 145-146).

The cause of the Peloponnesian War is given as identified by Thucydides: "The Spartans went to war [...] because they feared the growth of Athenian power ..." $(1.88,118.2$; p. 150), but Heller paints a more negative picture of Pericles, and ascribes a more sinister role to him:

And then, in $433 \mathrm{BC}$, Pericles, this leader of the democrats, builder of the Parthenon, sponsor of Aeschylus and Phidias [...], in the belief that war with Sparta was probable, deliberately took steps to make it inevitable (p. 150).

The ante-bellum events at Megara, Potidaea and Corcyra (Thuc. 1.24-88) are mentioned in passing, as are the speech of the Corinthians in a council meeting of the Spartans, and Pericles' response to it (1.119-124, 140-145; pp. 151-152). Next, the main events of the Archidamian War are described. Heller emphasises Pericles' integrity during the first Spartan invasion of Attica:

Pericles announced promptly that if his own estates were spared by the invading Spartans, he would donate them to the city (Thuc. 2.13.1, Plut. Vit. Per. 33; p. 148).

After a description of Pericles' war tactics (Thuc. 2. 14, 17; p. 153), the chronology of Thucydides, Book 2 is followed with a paraphrase of the funeral oration (Thuc. 2.3446, pp. 153-156) and a description of the plague and its effects on the beleaguered population of Athens (2.47-54, pp. 157-160). The last two items are reported at some length, although they do not substantially contribute to Heller's anti-war thesis. It would have carried more conviction had he attempted to deconstruct the Thucydidean Pericles' idealised claims contained in the speech. As in Thucydides, Book 2, this is followed by Pericles' last speech (2.60-64, pp. 160-161) and an evaluation of

50 Chapters VII-IX, XI / 15-20, 22-25; pp. 143-181, 201-230. 
Pericles' leadership (2.65, pp. 161-162). Although Heller has not deviated much from Thucydides' predominantly positive depiction of Pericles, he has clearly attributed a more belligerent role to Pericles in the outbreak of the Peloponnesian War.

After a paraphrase of the speeches of Cleon and Diodotus concerning the fate of the Mytileneans (3.36-50, pp. 167-171) and a short note on Spartan atrocities in Plataea (3.68, p. 172), Heller shows special interest in the group psychology of the civil war in Corcyra and in its influence on morality, ${ }^{51}$ as well as in Cleon's demagoguery $^{52}$ and his attempts at censuring Aristophanes (pp. 173-181). A notable omission is Thucydides' description of Cleon's maverick success at Pylos (4.3-41). The chapter called "Whose side were they on?", ostensibly on the civil war in Corcyra, suggests that Cleon has his heirs in twentieth-century demagogues, who also debase language and indoctrinate the populace to think in simplistic black-and-white terms with no shades of grey.

After the death of Cleon and Brasidas and the Peace of Nicias, the Melian debate and the destruction of Melos - "in that interval of peace that was known as the cold war" (p. 201) - are described in some detail. ${ }^{53}$ Next, the speeches of Nicias and Alcibiades on the eve of the Sicilian expedition are summarised (Thuc. 6.8-26, pp. 209-211), followed by a long mock-Platonic dialogue between Socrates and Alcibiades in which the roles of student and teacher are reversed (pp. 211-219). The function of this passage, like the Symposium passage earlier, is probably to question the character of a would-be empire-builder such as Alcibiades, thus underscoring Heller's anti-imperialist stance. Next, in quick succession, are described the mutilation of the Hermae (6.27-29, pp. 220-221), the departure of the Athenian expedition to Sicily (6.30-32, pp. 221-223), Alcibiades' defection, and his advice to Sparta (6.53, 61, 89-93; pp. 223-224). The Athenian defeat in Sicily and Nicias' surrender and death (7.84-87, pp. 225-226) are treated cursorily; an unexpected omission is the sea battle in the harbour of Syracuse (7.42-75).

For the end of the Peloponnesian War, Heller, of course, has to use Xenophon as hypotext. He describes Alcibiades' recall as general to Athens (Xen. Hell. 1.4.9, p. 227) and, finally, the Athenian defeat in 404 when the Peloponnesians tore down the city walls of Athens (Xen. Hell. 2.2.20, p. 228). ${ }^{54}$

For evidence, sometimes anecdotal, concerning Pericles and Alcibiades, as well as Alexander, Heller relies on Plutarch. He tells, for instance, how Pericles, when he was berated in the market-place by a displeased citizen who followed him home without ceasing in his abuse, directed a servant to light the way back to the man's house with a torch (Plut. Vit. Per. 5, p. 149). Next, he describes Pericles' relationship with Aspasia and his friendship with Anaxagoras, as well as the court cases against the latter two (Vit. Per. 4, 24, 32; pp. 149-150). Alcibiades' famous lisp is mentioned on more than one occasion (Vit. Alc.1, pp. 85, 214), and the incident is

\footnotetext{
51 Thuc. $3.70-85$.

52 In describing Cleon as a "McCarthyist demagogue", Seed 1989:202 astutely echoes Heller's implicit message that the abuse of power is a recurrent threat that spans centuries.

53 Thuc. 5.84-106 (pp. 201-207). The terminology used invites comparison with the twentiethcentury parallel of the Cold War between Russia and the United States.

54 Cf. p. 62.
} 
recalled when Socrates saved Alcibiades' life at Potidaea. ${ }^{55}$ Heller stresses Alcibiades' playboy reputation: his seduction of the wife of the Spartan king (Vit. Alc. 23, p. 89) and his extravagant spending on horses (Vit. Alc. 11, p. 181). His murder by Persian assassins at the request of Sparta, after the end of the Peloponnesian War, is recounted on two occasions (Vit. Alc. 39, pp. 89, 228-229).

A number of anecdotes relate to Alexander the Great. ${ }^{56}$ References to Alexander probably serve to contextualise Aristotle historically; moreover, the relationship between Aristotle and Alexander is implicitly compared to that between Socrates and Alcibiades, in that both pupils failed to live up to the high moral standards of their teachers.

From all this, it is clear that Heller has used a variety of classical and postclassical sources. He has done so extensively and, on the whole, meticulously. ${ }^{57}$ However, he has done his readers and his sources a disservice by not acknowledging these sources more consistently.

\section{$6 \quad$ Terminological and factual errata}

Although Heller has clearly gone to great lengths to give a true reflection of the history of the periods depicted in Picture This, the sections based on Athenian history are not without factual, terminological and chronological errata. ${ }^{58}$

A number of these relate to Pericles. When, for instance, Solon's reforms are dated to "a hundred years before Pericles" (p. 60), it is chronologically inexact. Solon's reforms can be dated to $c .594$ BC, exactly a century before the birth of Pericles, but one and a half centuries before Pericles in his prime became the most important politician in Athens. "A hundred years before Pericles" would therefore rather refer to $560-530 \mathrm{BC}$. When, on another occasion, Pericles is described as having suffered "parliamentary setbacks" (p. 27), it is terminologically incorrect. The Athens of Pericles did not know a parliament. The direct democracy of classical Athens would have been mystified by the limitations of a system whereby representatives are elected for four or five years, as required by a parliamentary system; each Athenian famously represented himself. The closest the Athenians came to a parliament was the "Council of 500", ten bodies of fifty men each serving for 36

\footnotetext{
55 However, at Socrates' insistence, Alcibiades instead of Socrates received a medal for the act of bravery (Plut. Vit. Alc. 7; Diog. Laert. 2.23; p. 87).

56 When an enraged Philip staggered drunkenly toward his son with drawn sword at Philip's wedding to Cleopatra at Pella, the nineteen-year-old Alexander is said to have wryly remarked: "See there [...], how the man who prepares to cross out of Europe to invade Asia is overturned so easily as he tries to cross a room" (p. 283; Plut. Vit. Alex. 9).

Alexander reputedly once asked the Cynic philosopher Diogenes what he could do for him; Diogenes answered that he could move out of his sunlight. Alexander retorted:

"If I were not Alexander [...], I would want to be Diogenes" (p. 35; Plut. Vit. Alex. 14). Again, when peace terms arrived in the field from the king of Persia, an adviser (Parmenio) recommended:

"If I were Alexander, I would accept these proposals". And so would he, responded Alexander, were he Parmenio (p. 35; Plut. Vit. Alex. 29).

$57 \quad$ But see Sections 4.3 and 6.

58 This appears to have escaped the notice of critics such as Craig and Seed.
} 
days at a time on a rotation basis. Again, in comparing the causes of the Peloponnesian War, the First Anglo-Dutch War of 1651 and the Vietnam War, Heller argues that "Pericles ... moved Athens ahead onto her self-destructive course of war with Sparta" (p. 132). Such an evaluation does not do justice to Pericles. Although Pericles was the architect of an Athenian imperialism that would lead to Sparta declaring war on Athens, his conservative war strategy, if Thucydides is to be believed, was not in itself destructive to Athens; that was the doing of less responsible successors of his such as Cleon (Thuc. 2.65).

In two instances, Heller involves Pericles in legislation or court cases pertaining to the theatre. When Pericles is said to have enacted a law "prohibiting reference to living Athenians in plays" (p. 147), Heller is probably confusing this alleged legislation with the so-called "Decree of Syracosios" in 414 BC (Vickers 1995:340), fifteen years after Pericles' death. On another occasion (p. 175), Heller claims that "Aristophanes was taken to court by Cleon for a play in which he blamed Pericles for starting the war and Athens and Cleon for continuing it". The context makes it likely that Babylonians is the play alluded to. In this play, produced in 426, the allied cities form a chorus of Babylonian slaves working at the mill of Demos, personifying Athens, and at the mercy of the supervisor Cleon; thus, according to the scholiast on Acharnians 378, Aristophanes directs his attack "against all the Athenian officials, whether elected or chosen by lot, and above all, against Cleon" (Van Steen 1994:213n.8). Allusions to this case occur in Acharnians (377-382, 502-506), but Pericles' name is not mentioned in literature on these passages. Perhaps Heller was thinking not of Babylonians but of Acharnians, where Dikaiopolis-aliasAristophanes $^{59}$ blames Pericles for being partly instrumental in starting the war (Ar. Ach. 515-539). Critics are still divided on the question of how seriously this passage should be taken (MacDowell 1995:59n.21, 60n.25).

It thus transpires that Heller has allowed some errors to creep into the sections of Picture This which deal with classical Athenian history. However, they are few in number. Such peccadilloes are overshadowed, perhaps, by the impressive arsenal of historical facts that he marshals in the course of the novel.

\section{Ideology: critique of imperialism}

Linda Hutcheon (1989:49) contends that "[i]deology [...] 'doxifies' or naturalizes narrative representation, making it appear as natural or common-sensical; it presents what is really constructed meaning as something inherent in that which is being represented". In describing, implicitly comparing, and sometimes overtly comparing the politics of classical Athens, seventeenth-century Holland and the U.S.A. in the twentieth-century, Heller's stance is not that of a neutral observer. As a critic of the Vietnam War, he selectively uses examples from history to point a moral for his contemporaries, or in Hutcheon's terms, to mask his "constructed" representation as the only possible one. In pre-postmodern parlance, he is simply being honestly subjective. In the process, he is critical of warmongering and imperialism, of corrupt

59 This is the only instance in surviving Old Comedy where a character on stage, as opposed to the Chorus, speaks in the first person on behalf of the poet (Slater 2002:50). 
leaders and wrong motives. His ideological stance is that of the sixties: a deeplyseated distrust, perhaps born in the McCarthyist era, of cynical and power-hungry politicians.

Early on, he points out similarities between the imperialism of the Dutch Republic and that of classical Athens (pp. 42-43). According to Seed (1989:206), Heller describes Athenian and Dutch foreign policy in such a way "that a continuity of imperialistic design takes shape and extends into American politics of the 1980s". This "continuity of imperialistic design" is explicitly formulated in a later passage dealing with the two dominant ideologies of the twentieth century:

One of the effects of capitalism is communism.

In the second half of the twentieth century, the contending superpowers of capitalism and communism coexisted in a symbiotic equilibrium of necessary evils and got on with each other much better than either wanted to admit. [...]

Leaders in both places never seemed to hate each other as much as they hated members of their own populations who differed with them and, as with ancient Athens, smaller nations attempting to evade their domination. [...]

The motives of Athenians in establishing democratic societies elsewhere were not to establish democratic societies but to remove hostile neighbors and obtain absolute compliance from societies guided by governments in liege to them.

In the eighty years of military strife in Greece after victory in the Persian wars, the sole diplomatic principle asserted by Athenians in debate was the right of the strong to suppress the weak (pp. 99-100).

Heller then proceeds to give examples of how this principle was applied, especially by the radical democrat Cleon (pp. 101-102). Indeed, this is but a confirmation of the Machiavellian principle of the right of the strongest as it is time and again highlighted by Thucydides. There are many examples of the principle of self-interest and its consequences in Picture This. As early as the Egyptian expedition of 459-454 (pp. 143-144), a warning is sounded when this principle leads to unnecessary loss of life. This is followed, in chronological sequence, by attempts at exercising unbridled power in Mytilene, Melos and Syracuse, with dire results for the vanquished. Let us take the Athenian expedition against Syracuse as a case study. Heller's description of the events prior to the Sicilian expedition is tinted with cynicism:

Thus were Athens and Sparta able to observe the terms of the Peace of Nicias while continuing to make war against each other in the cities of the third world (p. 118).

The use of the term "the third world" is modern and thus invites the parallel of two modern superpowers waging war in the third world. Such a parallel is explicitly provided by Heller in a later passage:

From Athens to Syracuse by oar and sail was just about equivalent to the journey by troopship today from California to Vietnam, or from Washington, DC, to the Beirut airport in Lebanon or to the Persian Gulf. 
Do not make war in a hostile distant land unless you intend to live there.

The people will outnumber you, your presence will be alarming, the government you install to keep order will not keep order, victory is impossible if the people keep fighting, there is only genocide to cope with determined local military resistance (p. 208).

A comparison is thus drawn between the Sicilian Expedition in the Peloponnesian War and American foreign policy in the twentieth century. Every clause in the last sentence is meant to be applied to Vietnam, first and foremost. This is probably the strongest authorial statement in Picture This on the Vietnam War. Elsewhere, this condemnation is forcefully reiterated:

[...] Lyndon B. Johnson [...] lied to the American people and the American Congress and secretly and deceitfully took the nation openly into a war in Southeast Asia it could not win and did not, persevering obstinately on that destructive course as resolutely as did Pericles when he moved Athens ahead onto her self-destructive course of war with Sparta (p. 132).

But let us return to Sicily. When the turncoat Alcibiades advises the Spartans about their strategy in Syracuse, he adapts his domino theory ${ }^{60}$ to fit the changed scenario:

If you [= the Spartans] do not fight them [= the Athenians] in Syracuse now, you will have to fight them in Sparta later, and Carthage and all Sicily will be on their side (p. 224; cf. p. 217).

Without Heller explicitly saying so, this turns ancient Athens and Sparta into an analogy of the USA and the USSR during the Cold War. Heller is not alone in thinking so. Stephen Hodkinson (2006:5) mentions that under the Presidency of Ronald Reagan, Henry S. Rowen, Chair of the National Intelligence Council, labelled the Soviet Union "a kind of Sparta writ large", and Alvin Bernstein, a former professor of ancient history who became Chairman of the Department of Strategy at the Naval War College, argued that there were genuine parallels between what he called the "militaristic states" of Sparta and the Soviet Union.

What I have called "authorial statements" are borne out by personal statements by Heller about the Vietnam War. Seed (1989:86) quotes Heller as having said:

I am against the military intervention of the US in Vietnam. It was a ghastly choice, and thousands die each month because of it ... [W] ought to stop murdering Asians. We ought to stop sending young American boys, against their will, ten thousand miles away to be killed and mutilated in battle against people that do not threaten us and did us no harm.

$60 \quad$ See Section 4.3 . 
Sir Winston Churchill is reputed to have said that democracy is the worst possible form of government, except all others. The conundrum with which Heller confronts fellow-democrats is this: how should one account for the fact that, in times of (cold) war, both democratic Athens and the democratic U.S. tend to practise internal suppression and external imperialism? How can this be reconciled with the vaunted freedom associated with democracy?

Evaluation

Starting with the ekphrasis of a Rembrandt painting, Joseph Heller has written 351 pages of what purports to be a novel, but what proves to be a dialogue with, and sometimes almost a kind of diatribe inspired by, classical Athens. His background in Classics has enabled him to use classical sources extensively and impressively, if not always faultlessly. He has introduced non-classicist readers to the world of Pericles and Alexander, non-historians to the fifth and the fourth century BC, and non-philosophers to the minds of Socrates, Plato and Aristotle; he has invited classicists to ask new questions of the classical age of Athens, and Americans to confront neo-conservative imperialism, whether in Vietnam or Afghanistan.

Much of what he says is not new. To the extent that he adheres to his sources, innovation is no option. Thus, he cannot but confirm the reputation of Cleon as a warmonger or Alcibiades as a playboy; he points out the standard antithesis between Plato as idealist and Aristotle as empiricist. In other cases, however, he has opted for at least a shift in emphasis. Heller's Pericles, for instance, has to forgo his Thucydidean idealisation when he is debunked as a cynical warmonger; the Platonic depiction of Socrates is deconstructed and thus the manner of Socrates' death is left open-ended. In one case, however, Heller has created a totally new character: the grumpy, but endearingly human, magical-realist Aristotle-as-subject-of-the-painting. This is, perhaps, his most innovative contribution to the novel.

On a political level, Heller vociferously criticises the excesses of war and imperialism. Questioning the ability of leaders of democracies, whether in Athens or in Washington, to lead with integrity, he remains irredeemably cynical about power, offering no constitutional solution for its abuse. Heller's copious use of classical intertexts to act as an implicit parallel to, and thus as a guideline for, the present deflects criticism that Picture This is a mere political pamphlet or a moralising tract explicitly pontificating about Vietnam.

Throughout, Heller's style is characterised by his trademark use of irony. But underlying the surface humour is a seriousness of intent that is reflected in his subject matter. Indeed, as he said in an interview: "In what I hope is an amusing way, it's really an extremely pessimistic book" (Craig 1997:187). This statement is confirmed by a series of paratextual epigraphs at the start of the novel which culminate with the observation:

History is bunk, says Henry Ford, the American industrial genius, who knew almost none (p. 11). 
At the end of the novel, this is reiterated, with the addition of a cynical comment:

You will learn nothing from history that can be applied (p. 350).

Craig (1997:194) astutely remarks that "Heller paradoxically uses historical research to establish the premise that nothing can be learnt from history". But in spite of Heller's pessimism, his novel exposes readers to a broadening of their horizons, perhaps challenging their ideological preconceptions of Athens or Washington.

Picture This is a strange work - generically, narratologically, structurally. In part, this could be ascribed to the idiosyncrasies of postmodernism. As a classicist and a comparatist, I found that it is redeemed not only by Heller's inimitable use of irony, but also by the extensive use of classical intertext. At a time when reception studies is flourishing, a novel seeking to demonstrate a link between antiquity and the present should be welcomed - the more so if it is written by as innovative and stimulating an author as Heller.

\section{BIBLIOGRAPHY}

Craig, D M 1997. Tilting at mortality. Narrative strategies in Joseph Heller's fiction. Detroit: Wayne State University Press.

Furlani, A 1995. "Brisk Socratic dialogues": Elenctic rhetoric in Joseph Heller's Something Happened. Narrative 3.3:252-270.

Genette, G 1982. Palimpsestes. La littérature au second degré. Paris: Seuil.

Gill, C 1973. The death of Socrates. CQ 23:25-28.

Golden, L (trans.) \& Hardison, O B (commentary) 1968. Aristotle's Poetics. A translation and commentary for students of literature. Englewood Cliffs: Prentice-Hall.

Heller, J 1988. Picture This. London: Picador / Pan Books.

Hodkinson, Stephen 2006. Spartan militarism - a modern mirage? Omnibus 52:4-5.

Hutcheon, L 1988. A poetics of postmodernism. History, theory, fiction. New York \& London: Routledge.

Hutcheon, L 1989. The politics of postmodernism. London \& New York: Routledge.

MacDowell, D M 1995. Aristophanes and Athens. Oxford: Oxford University Press.

McHale, B 1987. Postmodernist fiction. New York \& London: Methuen.

Potts, S W 1982. From here to absurdity. The moral battlefields of Joseph Heller. San Bernardino: The Borgo Press.

Reilly, C and Heller, J 1998. An interview with Joseph Heller. Contemporary Literature 39.4:507-522.

Seed, D 1989. The fiction of Joseph Heller: Against the grain. London: Macmillan.

Slater, N W 2002. Spectator politics: metatheatre and performance in Aristophanes. Philadelphia: University of Pennsylvania Press.

Steinz, P 1994. Socrates in New York. Review of Closing Time. Cultureel Supplement NRC Handelsblad, 21-10-94.

Stern, F C 1988. Heller's hell: Heller's later fiction, Jewishness, and the liberal imagination. Melus 15.4:15-37. 
Van Heerden, E 1994. Vanuit eie werk: Die skrywer as historiograaf. Tydskrif vir Letterkunde 32.3:1-15.

Van Steen, G A H 1994. Aspects of "public performance" in Aristophanes' Acharnians. Ant. Cl. 63:211-224.

Vickers, M 1995. Alcibiades at Sparta: Aristophanes'Birds. CQ 45 (ii):339-354. http://www.mishalov.com/Heller.html 